\title{
Upaya Memutus Rantai Infeksi oleh Perawat dengan Pemakaian Alat Pelindung Diri (APD) yang benar
}

\author{
Rizqiyatul Laili
}

e-mail : $\underline{\text { laili.rizqiyatul@gmail.com }}$

\section{LATAR BELAKANG}

Rumah sakit sebagai salah satu sarana kesehatan yang memberikan pelayanan kesehatan kepada masyarakat, memiliki peran yang sangat penting dalam meningkatkan derajat kesehatan masyarakat, dengan melaksanakan upaya kesehatan yang berhasil guna dan berdaya guna terhadap pelayanan masyarakat, oleh karena itu rumah sakit dituntut untuk dapat memberikan pelayanan yang bermutu sesuai dengan standar yang telah ditentukan.

Mutu Pelayanan Rumah Sakit dapat diukur dengan salah satu indikator angka kejadian infeksi nosocomial. Infeksi nosokomial adalah infeksi yang timbul di rumah sakit, di mana pasien tersebut sebelumnya tidak menderita infeksi dan tidak dalam masa inkubasi infeksi tersebut. Infeksi nosokomial merupakan salah satu penyebab utama dari meningkatnya angka morbiditas dan mortalitas, yang dapat menghambat proses penyembuhan sehingga mengakibatkan masalah baru dalam bidang kesehatan, antara lain meningkatnya hari rawat dan bertambahnya biaya perawatan serta pengobatan pasien di rumah sakit (WHO, 2005).

Masyarakat yang menerima pelayanan kesehatan, tenaga kesehatan dan pengunjung di rumah sakit dihadapkan pada risiko terjadinya infeksi atau infeksi nosokomial, sekitar $20 \%$ disebabkan karena perawatan atau datang berkunjung ke rumah sakit. Menur ut tim Pencegahan dan Pengendalian Infeksi di Rumah Sakit (PPIRS, 2007), beberapa faktor yang sering menimbulkan terjadinya infeksi nosokomial antara lain; peningkatan jumlah pasien yang dirawat di rumah sakit, kontak langsung antara petugas yang terkontaminasi kuman dengan pasien, penggunaan peralatan kedokteran yang telah terkontaminasi kuman, dan kondisi 
pasien yang lemah akibat penyakit yang sedang dialaminya. Hasil penelitian menunjukkan $32 \%$ infeksi nosokomial dapat dicegah.

\section{METODE}

Metode penelitian yang digunakan adalah literature review. Dengan melakukan analisis dan kajian bebas pada jurnal dan textbook yang sudah terjamin datanya dengan tahun 2012-2020. Pengambilan informasi melalui jurnal dan textbook adalah untuk mendapatkan berbagai informasi yang lengkap dan akurat dengan cara melakukan penyimpulan dari jurnal dan textbook tersebut. Penyimpulan yang dilakukan adalah dengan menggunakan bahasa sendiri tanpa ada meniru karya orang lain.

\section{HASIL}

Berdasarkan jurnal dan textbook tersebut, didapatkan bahwa infeksi nosokomial dipengaruhi oleh perilaku tenaga kesehatan. Dengan demikian untuk mencapai keberhasilan program pencegahan dan pengendalian infeksi, dituntut pengetahuan dan sikap tenaga kesehatan untuk segera melakukan pencegahan dan pengendalian infeksi nosocomial.

Salah satu cara untuk mengatasi cara tersebut yaitu dengan memahami perilaku yang berhubungan dengan pencegahan infeksi seperti penggunaan APD yang benar dan medication safety.

Penularan penyakit atau infeksi dapat beresiko terjadi pada semua petugas kesehatan apabila selama melakukan tindakan pada pasien tidak memperhatikan tindakan pencegahan (universal precaution) dengan cara menggunakan APD. Penggunaan APD merupakan usaha perawat menyediakan lingkungan yang bebas dari infeksi sekaligus sebagai upaya perlindungan diri dari pasien terhadap penularan penyakit (Putra, 2012). Kepatuhan perawat dalam penggunaan APD berpengaruh pada penularan penyakit. Jika kepatuhan penggunaan APD diabaikan, maka tentunya akan semakin bertambah risiko tertular penyakit misalnya hepatitis, HIV/AIDS, dan COVID-19. 


\section{PEMBAHASAN}

APD memiliki peran yang penting dalam upaya mengeliminir transmisi agent penyakit infeksi baik dari lingkungan rumah sakit, dari pasien ke perawat maupun dari pasien ke pasien lainnya maupun infeksi yang terjadi pada pasien itu sendiri. Untuk itu, perawat wajib memiliki pengetahuan mengenai pemakaian APD secara benar.

APD perawat ketika praktek terdiri dari sarung tangan, alat pelindung wajah, penutup kepala, gaun pelindung atau apron, alas kaki atau sepatu,

\section{Sarung tangan}

Pemakaian sarung tangan merupakan bagian penting dari standar precaution bagi perawat yang sering berinteraksi dengan pasien maupun alat-alat yang terkontaminasi. Sarung tangan dapat membantu perawat untuk melindungin tangan dari kontak dengan darah, semua jenis cairan tubuh, sekret, kulit yang tidak utuh, selaput lendir pasien dan benda yang terkontaminasi. Hal yang perlu diperhatikan dalam penggunaan sarung tangan :

a. Mencuci tangan dengan sabun sebelum dan sesudah menggunakan sarung tangan,

b. Mengganti sarung tangan jika berganti pasien atau sobek,

c. Mengganti sarung tangan segera setelah melakukan tindakan,

d. Menggunakan sarung tangan saat menggunakan alat nonkontaminasi,

e. Menggunakan satu sarung tangan untuk satu prosedur tindakan,

f. Menghindari kontak dengan benda-benda selain dalam tindakan,

g. Menghindari penggunaan atau mendaur ulang kembali sarung tangan sekali pakai.

2. Alat pelindung wajah

Alat pelindung wajah merupakan peralatan wajib perawat untuk menjaga keamanan dirinya dalam menjalankan asuhan keperawatan. Alat pelindung diri 
wajah dapat melindungi selaput lendir dibagian mulut, hidung dan mata perawat terhadap resiko percikan darah maupun cairan tubuh manusia.

Alat pelindung wajah terdiri dari masker dan kacamata pelindung. Kedua jenis alat pelindung diri tersebut dapat digunakan terpisah maupun bersamaan sesuai dengan jenis tindakan.

Masker bagian alat pelindung muka khususnya untuk melindungi mulut dan hidung perawat ketika berinteraksi dengan pasien. Masker dianjurkan untuk selalu digunakan perawat ketika melakukan tindakan dengan semua pasien khususnya pasien TB. Hal ini diharapkan mampu melindungi perawat terhadap penularan melalui udara. Secara umum masker dibagi menjadi dua jenis yaitu masker standar dan masker khusus. Beberapa hal yang perlu diperhatikan ketika menggunakan masker :

a. Memasang masker sebelum memasang sarung tangan,

b. Tidak dianjurkan menyentuh masker ketika menggunakannya,

c. Mengganti masker ketika kotor dan lembab,

d. Melepas masker dilakukan setelah melepas sarung tangan dan cuci tangan,

e. Tidak membiarkan masker menggantung dileher,

f. Segera melepaskan masker dilakukan jika tidak digunakan

g. Tidak dianjurkan menggunakan kembali masker sekali pakai. Kacamata sebagai bagian dari APD yang bertujuan melindungi mata. Kacamata digunakan untuk mencegah masuknya cairan darah maupun cairan tubuh lainnya pada mata.

\section{Penutup kepala}

Penutup kepala sebagai bagian dari standard precaution memilikin fungsi dua arah. Fungsi pertama, penutup kepala membantu mencegah terjadinya percikan darah maupun cairan pasien pada rambut perawat. Selain itu, penutup kepala dapat mencegah jatuhnya mikroorganisme yang ada di rambut maupun kulit kepala ke area steril Kedua fungsi tersebut sangat penting untuk diperhatikan oleh perawat.

4. Gaun pelindung 
Gaun pelindung atau baju kerja atau celemek dapat memberikan manfaat bagi perawat untuk melindungi kulit dan pakaian dari kontaminasi cairan tubuh pasien. Gaun pelindung wajib digunakan ketika melakukan tindakan irigasi, menangani pasien dengan perdarahan, melakukan pembersihan luka, maupun tindakan lainnya yang terpapar dengan cairan tubuh pasien. Gaun pelindung terdiri dua jenis gaun pelindung yaitu steril dan non steril. Perawat sebagai pemberi asuhan keperawatan perlu mengetahui penggunaan gaun pelindung secara benar. Penggunaan gaun pelindung secara benar dapat melindungi perawat dari bahaya infeksi. Hal-hal yang perlu diperhatikan perawat dalam penggunaan gaun pelindung meliputi (Rosdahl \&Merry, 2008):

a. Bagian dalam gaun adalah bersih dan bagian luarnya adalah yang nantinya harus dijaga (sesuai dengan jenis gaunnya),

b. Ukuran gaun perlindung harus cukup panjang dan dapat menutupi seragam perawat bagian depan dan belakang namun tidak menutupi lengan,

c. Jika menggunakan seragam lengan panjang, seragam harus digulung diatas siku dan perawat baru menggunakan gaun pelindung,

d. Ketika hendak melepaskan gaun pelindung, cara melepaskan adalah dari dalam keluar untuk mencegah kontaminasi cairan dengan seragam,

e. Setelah melepas gaun jangan lupa untuk selalu mencuci tangan sebelum melakukan aktivitas lain.

\section{Alas kaki (sepatu)}

Alas kaki merupakan bagian dari APD yang perlu untuk digunakan. Alas kaki melindungi perawat ataupun petugas kesehatan terhadap tumpuhan atau percikan darah maupun cairan tubuh yang lain. Penggunaan alas kaki juga bertujuan untuk mencegah kemungkinan tusukan benda tajam maupun kejatuhan alat Kesehatan. Standar alas kaki yang tertutup seluruh ujung jari dan telapak kaki serta terbuat dari bahan yang mudah dicuci dan bahan tusukan. Penggunaan alas kaki termsuk juga sepatu yang dipakai sehari-hari harus memenuhi syarat dan juga penggunaan sepatu khusus seperti sepatu khusus diruang tertentu misal ruang operasi, ICU, isolasi, ruang bersalin, ruang pemulasaraan jenazah. 


\section{PENUTUP}

Pemakaian Alat Pelindung Diri (APD) yang benar pada perawat sangat berpengaruh untuk memutus rantai infeksi. Dengan diterapkannya dan disiplinnya perawat menggunakan APD yang benar, maka perawat telah menyediakan lingkungan yang bebas dari infeksi sekaligus sebagai upaya perlindungan diri dari pasien terhadap penularan penyakit. Namun jika pemakaian APD yang benar diabaikan, maka tentunya akan semakin bertambah risiko tertular penyakit misalnya hepatitis, HIV/AIDS, dan COVID-19.

\section{DAFTAR PUSTAKA}

Djaafar Nurseha, 2013. PENGEMBANGAN TINDAKAN PENCEGAHAN INFEKSI NOSOKOMIAL OLEH PERAWAT DI RUMAH SAKIT BERBASIS HEALTH BELIEF MODEL. Jurnal Ners Vol. 8 No. 1

Hayulita S., Frenky P,. 2014. Hubungan Motivasi dengan Penggunaan Alat Pelindung Diri oleh Perawat Pelaksana di Ruang Rawat Inap RSI Ibnu Sina Bukittinggi. Diakses tanggal 11 Januari 2017.

Lardo, 2016. Infection Control Risk Assesment (ICRA). CDK-238/ Vol. 43 no. 3. Ningsih,EW. 2013. Hubungan Tingkat antara Pengetahuan dan motivasi perawat dengan perilaku Pencegahan Infeksi Nosokomial di rumah sakit Umum Daerah Sukoharjo (Jurnal Elektronik) dikases 24 Pebruari 2016 ; Http:/www. ums.ac.id

Novertha ED, Chandra F, Enalia Y. 2012. Gambaran pengetahuan dan praktik mahasiswa kepaniteraan klinik tentang pencegahan penularan infeksi hepatitis B. Jurnal kedokteran gigi universitas Riau. 1-7.

Putra M. K. P. 2012. Hubungan Tingkat Pengetahuan dan Sikap dengan Perilaku Penggunaan Alat Pelindung Diri pada Mahasiswa Profesi Fakultas Ilmu Keperawatan Universitas Indonesia. http://lib.ui.ac.id Diakses tanggal 5 Oktober 2016. 
Rutala, William A, Weber, David J. Weber. 2013. Disinfection and sterilization: An overview. American Journal of Infection Control. 41 (5) Supplement: S2-S5

Simamora, R. H. (2019). Pengaruh Penyuluhan Identifikasi Pasien dengan Menggunakan Media Audiovisual terhadap Pengetahuan Pasien Rawat Inap. Jurnal Keperawatan Silampari, 3(1), 342-351.

Simamora, R. H. (2020). Learning of Patient Identification in Patient Safety Programs Through Clinical Preceptor Models. Medico Legal Update, 20(3), 553556.

Suharto, Ratna Suminar. 2016. HUBUNGAN PENGETAHUAN DAN SIKAP PERAWAT DENGAN TINDAKAN PENCEGAHAN INFEKSI DI RUANG ICU RUMAH SAKIT. Jurnal Riset Hesti Medan, Vol. 1, No. 1

Sukarsih, 2015, Modul Pengendalian Infeksi Silang, Politeknik Kesehatan Jambi Program Studi DIV Keperawatan Gigi

Wijayanto, 2015. Hubungan Motivasi Perawat Dengan Perilaku Pemakaian Alat Pelindung Diri Saat Melakuakan Kemoterapi di Ruang Rawat Inap RSUP DR. Moewardi. Diaksest tanggal 1 September 2016. 